\title{
Layanan Pendidikan bagi Anak Gifted
}

\section{Education Services for Children Gifted}

\author{
Muhammad Idrus \\ Magister Psikologi UAD
}

\begin{abstract}
Abstrak
Banyak anak-anak berbakat tidak menerima layanan pendidikan yang sesuai untuk mereka. Dengan mengabaikan untuk memberi mereka pendidikan yang layak yang harus diterima, akan membuat anak-anak berbakat tidak dapat tumbuh dan berkembang aspek bakat mereka. Monks mengajukan konsep "model Triadic bakat" sebagai model perbaikan untuk "Tiga-cincin Konsepsi bakat "yang diusulkan oleh Renzulli dengan menambahkan unsur keluarga, sekolah dan teman sebaya (lingkungan atau lingkungan), untuk melengkapi konsep Renzulli yang terdiri dari kreativitas, komitmen tugas, dan kemampuan atas rata-rata. Konsep biarawan mempertimbangkan pendidikan yang layak bagi anak-anak berbakat untuk mengembangkan bakat mereka, seperti kelas khusus, kelas akselerasi atau kelas pengayaan.
\end{abstract}

Kata kunci: Model Triadic bakat, Tiga-Ring Konsepsi Bakat. Pendidikan Bagi Anak berbakat

\section{Abstract}

Many gifted children are not receiving appropriate educational services for them. By neglecting to give them the proper education which they should received, will making gifted children can not growing and developing aspects of their giftedness.Monks proposed the concept of "Triadic model of giftedness" as an refinement model for the "Three -Ring Conception of giftedness" which proposed by Renzulli by adding elements of family, school and peers (milieu or the environment), to furnish the Renzulli concept which consists of creativity, task commitment, and ability above average. Monks concepts consider the proper education for gifted children to develop their giftedness, such as special classes, accelerated classes or enrichment classes

Keyword: Triadic model of giftedness, Three-Ring Conceptions of Giftedness. Pendidikan bagi anak gifted

\section{Pendahuluan}

Disadari bahwa setiap individu lahir dengan keistimewaan yang khas, dan tidak sama antar individu satu dengan lainnya. Berbagai keistimewaan individual itulah yang nanti pada akhirnya kelak akan menjadikan siapa dirinya. Hanya saja segala keistimewaan tersebut tidak dapat berkembang secara optimal jika tidak didukung dengan faktor-faktor lain yang memungkin tumbuhberkembangnya potensi istimewa tersebut. Hal tersebut sebagaimana diungkap Bainbridge (Bainbridge, 2014), bahwa "....gifted children may not reach their potential if they are not provided with an appropriate educational environment...". Dengan begitu, sebagai syarat bagi keberkembangan potensi keberbakatan individu, maka layanan pendidikan yang sesuai dengan kebutuhan individual anak gifted harus terlebih dahulu diciptakan.

Selain itu, yang juga patut disadari oleh para orangtua dan pendidik 
adalah keistimewaan yang ada pada diri anak akan memiliki keterbatasan, sehingga jangan pernah berpikir bahwa anak-anak dengan kemampuan istimewa dapat mengatasi masalah yang dihadapinya dengan kemampuan yang dimilikinya sendiri, bahkan tidak jarang justru karena kemampuan istimewanya menjadikan anak-anak mengalami situasi dilematis yang sulit dipecahkannya sendiri. Hal tersebut sebagaimana diungkap Smutny (2000) bahwa karena keingin-tahuan mereka yang intens terhadap sesuatu, memungkinkan mereka memperoleh kesulitan dan karena mereka mereka mungkin memiliki tingkat energi super tinggi dan menjadi sangat sensitif dan perfectionistic. Pada akhirnya anak-anak muda berbakat beresiko untuk kebosanan, frustrasi dan depresi.

Pada saat-saat seperti itu, orang tua dan guru memiliki peran untuk membantu mengatasi masalah yang dihadapi anak. Terkait dengan relasi orang tua, guru dan siswa dalam pembelajaran, Ford dan Trotman (Ford, Ford, \& Trotman, 2001) menyatakan bahwa relasi yang positif antara orang tua, guru dan siswa menjadi dasar utama bagi keberhasilan siswa di sekolahnya. Relasi orang tua-guru-siswa menjadi sangat penting bagi pertumbuhan dan keberkembangan keberbakatan yang dimiliki anak. Dengan begitu menjadi penting bagi para orang tua menjadi kewajiban untuk secara cermat mengamati anak-anaknya, memberikan layanan pendidikan yang dibutuhkan, demikian juga hendaknya para pendidik diharapkan dapat menemukan dan memahami potensi setiap individu didiknya

Salah satu keistimewaan pada anak adalah adanya keberbakatan, atau banyak yang menyebutnya sebagai anak gifted. Anak berbakat (gifted) memiliki kecerdasan di atas rata-rata biasanya dengan IQ diatas 130, dan memiliki bakat unggul di satu atau beberapa bidang, seperti seni, musik atau matematika.

Menurut Semiawan dkk. (Semiawan, Munandar, \& Munandar, 1984) anak berbakat berbeda dengan anak pintar.

"Bakat berarti punya potensi, sedangkan pintar bisa didapat dari tekun mempelajari sesuatu, tapi meski tekun namun tak berpotensi, seseorang tak akan bisa optimal seperti halnya anak berbakat. Kalau anak tak berbakat musikal, misalnya. Biar dikursuskan musik sehebat apa pun, ya, kemampuannya sebegitu-begitu saja. Tak akan berkembang Sebaliknya, jika anak berbakat tapi lingkungannya tak menunjang, is pun tak akan berkembang."

Merujuk pendapat di atas keberbakatan yang dimiliki seseorang hanya akan dapat berkembang baik jika lingkungan sekitarnya mendukung berkembangnya keberbakatan yang dimilikinya, sebaliknya seberapapun besar bakat yang dimiliki individu, akan tetapi lingkungannya tidak kondusif bagi berkembangnya bakatnya, maka bakat yang telah ada tidak dapat berkembang secara optimal. Bahkan mungkin akan hilang begitu saja. Pada sisi ini, peran pemberian atau layanan pendidikan pada anak berbakat, agar keberbakatan yang dimiliki individu dapat berkembang sesuai dengan yang seharusnya.

\section{Studi Literatur}

\section{Pengertian Anak Gifted}

Istilah anak gifted atau gifted children dalam bahasa Indonesia sering digunakan untuk menyebut anak berbakat, anak luar biasa, dan untuk anak-anak jenius. Beberapa kalangan ahli anak berbakat sering 
membagi keberbakatan dalam tingkatan IQ, yaitu $130-140$ adalah moderate gifted, 140- 150 adalah highly gifted, dan $>150$ adalah anak jenius.

Kurang lebih 2000 tahun lampau, Plato (Akbar \& Hawadi, 12 Januari 2002) mendeskripsikan orang-orang dengan intelektual yang superior sebagai men of gold, untuk membedakannya dengan silver iron, atau brass. Anak-anak emas Plato ini adalah anak laki- laki dari Patrician class, yang jumlahnya sangat kecil sekali dalam populasi dan sangat selektif.

Ormrod (2009) mendefinisikan keberbakatan sebagai kemampuan atau bakat yang sangat tinggi di satu atau lebih bidang (misalnya dalam matematika, sains, menulis kreatif, seni atau musik). Definisi tentang gifted yang dilakukan oleh banyak pakar psikologi biasanya selalu dilakukan dengan menyebut kriteria tentang anak berbakat itu sendiri. Seperti definisi keberbakatan yang diajukan oleh Marland (dalam Report to congress of the United States by the US Commisioner of Education (Marland, 1985),

"...children capable of high performance may not have demonstrated it as high achievement, but can have potential in any of the following areas singly or in combination. 1. general intellectual ability 2. specc academic aptitude 3 . creative or productive thinking 4 . leadership ability 5 . visual and performing arts 6 . psychomotor ability

Dad paparan yang dikemukakan oleh Marland ini, keberbakatan dimaknai sebagai anak yang memiliki kemampuan tinggi dapat dalam satu bidang tertentu, tetapi tidak menutup kemungkinan kemampuan yang dimiliki lebih dari satu bidang.
Renzulli (Monks \& Boxtel, 1985) mengidentifikasikan bahwa seorang anak yang dapat dikatakan sebagai anak berbakat jika is mempunyai: (1) inteligensia yang tinggi di atas ratarata (2) kreativitas yang tinggi; (3) komitmen pada tugas yang tinggi. Gambaran model definisi yang diajukan oleh Renzulli ini kemudian disebut sebagai The Three-ring conception of giftedness dari Renzulli. Gambaran tersebut sebagaimana gambar berikut:

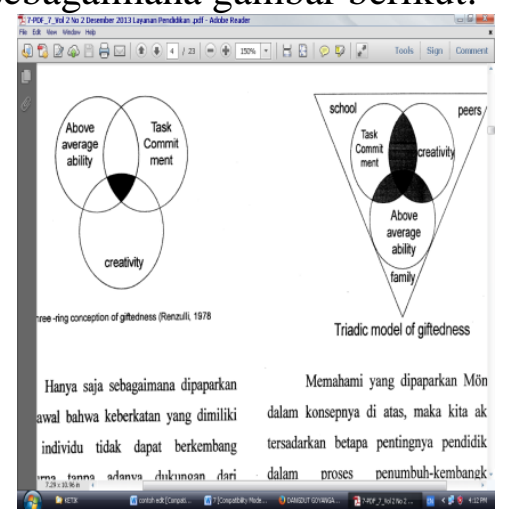

three -ring conception of giftedness (Renzulli, 1978)

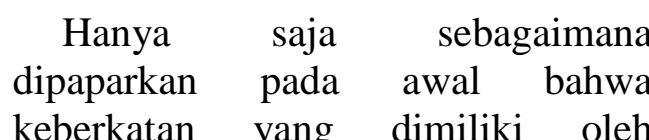
individu tidak dapat berkembang sempurna tanpa adanya dukungan dari keluarga, sekolah dan lingkungan sekitar. Mengacu pada hal tersebut pada akhirnya Monks menambahkan aspek keluarga, sekolah, dan lingkungan dalam model yang dibuat oleh Renzulli yang kemudian dikenal dengan nama Triadic model of giftedness atau dikenal juga dengan istilah Triadik Renzulli-Monks. Dijelaskan oleh Monks \& Ypenburg (dalam Maria) Bagaimana Pendidikan yang Cocok untuk Anak Berbakat dengan Perkembangan Disinkroni?, 11 Desember 2004) bahwa pada model yang diajukan Renzulli, keberbakatan (giftedness) itu tidak akan terwujud jika tidak mendapatkan dukungan yang baik dari sekolah, 
keluarga, dan lingkungan dimana si anak tinggal, Gambar dari model yang diajukan Monks sebagaimana berikut:

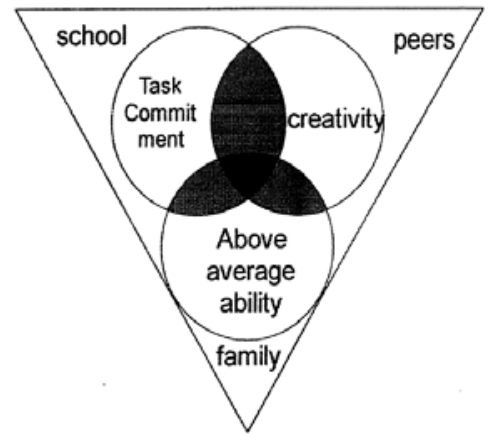

Triadic model of giftedness

Memahami yang dipaparkan Monks dalam konsepnya di atas, maka kita akan tersadarkan betapa pentingnya pendidikan dalam proses penumbuh-kembangkan keberkatan yang dimiliki individu. Tanpa adanya pelayanan dan pemberian pendidikan yang tepat dan sesuai karakteristik anak berbakat, maka yang akan terjadi mungkin sebaliknya. Bukan hanya ketertutupan atau hilangnya potensi individu yang dimaksud, bahkan mungkin yang terjadi adalah sebaliknya dengan menganggapnya sebagai anak yang selalu bermasalah atau anak yang mengalami gangguan kepribadian.

Pada sisi tersebut kerap terjadi kesalahan dalam diagnosa yang dilakukan terhadap anak berbakat ini. Hal tesebut sebagaimana dikutip oleh Maria Van Teil (Maria, Gifted atau Autisme: Bagaimana membedakannya? 11 December 2004), bahwa banyak dilaporkan adanya overdiagnosa dan misdiagnosa terhadap anak-anak gifted (anak berbakat atau anak luar biasa) terutama yang saat balitanya mengalami perkembangan tidak sinkron (disinkronitas perkembangan) dan menerima berbagai diagnosa gangguan mental dan perilaku atau disorder (Webb, 2000; van Vugt-van de Moosdijk, 2002 dalam Maria Van Teil, 2004).

Lebih lanjut dikutip Maria Van Teil (Maria, Gifted atau Autisme: Bagaimana membedakannya?, 11 December 2004) bahwa para individu berbakat itu bukan hanya menerima kesalahan diagnosis, tetapi juga menerima overterapi yang tidak jarang merupakan terapi non medik dan radikal. Tidak jarang mereka yang tergolong anak gifted, karena perilakunya sering dikelompokkan pada kelompok yang oleh van Vugt van de Moosdijk diistilahkan dengan nama PDDNOS (Pervasive Developmental Disorder Not Otherwise Specified) karena mereka tidak secara penuh dapat memenuhi kriteria autisme. Artinya, orang kerap melihat para anak gifted ini sebagai penyandang autis, meski tidak semua karakteristik anak autis pada mereka.

\section{Karakteristik Individu Gifted Dan Masalah Yang Dihadapi}

Ada banyak hal yang menjadi karakteristik khas anak-anak gifted, beberapa di antaranya adalah:

a. Kemampuan inteligensi umum yang sangat tinggi, biasanya ditunjukkan dengan perolehan tes inteligensi yang sangat tinggi, misal IQ diatas 130.

b. Bakat istimewa dalam bidang tertentu, misalnya bidang bahasa, matematika, seni, dan lain-lain. Hal ini biasanya ditunjukkan dengan prestasi istimewa dalam bidang-bidang tersebut.

c. Kreativitas yang tinggi dalam berpikir, yaitu kemampuan untuk menemukan ide-ide baru.

d. Kemampuan memimpin yang menonjol, yaitu kemampuan untuk mengarahkan dan mempengaruhi orang lain untuk bertindak sesuai dengan harapan kelompok.

e. Prestasi-prestasi istimewa dalam bidang seni atau bidang lain, 
misalnya seni musik, drama, tari, lukis, dan lain-lain.

Ormrod (Ormrod, 2008) mengidentifikasi beberapa kelebihan yang dimiliki anak gifted ini yaitu:

a. Perbendaharaan kata yang kaya, kemampuan berbahasa yang tinggi dan keterampilan membaca di atas rata-rata

b. Pengetahuan umum yang kaya mengenai dunia

c. Kemampuan belajar lebih cepat, mudah, mandiri disbanding teman-teman sebayanya

d. Proses kognitif dan strategi belajar yang lebih canggih dan efisien

e. Fleksibilitas yang lebih besar dalam hal gagasan dan

\begin{tabular}{|c|c|}
\hline Karakteristik & \\
\hline $\begin{array}{l}\text { 1. Belajar dengan cepat/mudah } \\
\text { 2. Dapat membaca secara intensif } \\
\text { 3. Memiliki perbendaharaan kata } \\
\text { yang bias } \\
\text { 4. Memiliki banyak informasi } \\
\text { 5. Memiliki perhatian yang cukup } \\
\text { lama } \\
\text { 6. Memiliki rasa ingin tahu atau } \\
\text { interes terhadap berbagai hal } \\
\text { 7. Bekerja secara mandiri } \\
\text { 8. Senang mengamati } \\
\text { 9. Memiliki rasa humor } \\
\text { 10. Mengerti atau mengenal } \\
\text { hubungan-hubungan } \\
\text { 11. Memiliki prestasi akademik } \\
\text { yang tinggi } \\
\text { 12. Lancar dalam berbahasa } \\
\text { 13. Individualistik } \\
\text { 14. Memiliki motif intrinsik }\end{array}$ & $\begin{array}{l}\text { 1. Mengingat dan menguasai fakta-fakta secara } \\
\text { cepat } \\
\text { 2. Membaca banyak buku dan menggunakan } \\
\text { perpustakaan pribadi } \\
\text { 3. Dapat mengkomunikasikan berbagai } \\
\text { gagasan dengan baik } \\
\text { 4. Cepat mengingat dan merespon } \\
\text { 5. Menyelesaikan tugas-tugas } \\
\text { 6. Banyak mengajukan pertanyaan, atau } \\
\text { memperoleh berbagai gagasan } \\
\text { 7. Merancang sesuatu di luar tugasnya } \\
\text { 8. Mengenal masalah } \\
\text { 9. Dapat menertawakan diri sendiri } \\
\text { 10. Dapat memecahkan masalah-masalah sosial } \\
\text { sendiri } \\
\text { 11. Dapat mengerjakan tugas-tugas sekolah } \\
\text { dengan baik } \\
\text { 12. Memiliki perbendaharaan kata yang luas, } \\
\text { dan dapat mengarahkan teman sebaya } \\
\text { dengan cam yang positif } \\
\text { 13. Senang mempertahankan pendapat sendiri, } \\
\text { dan memiliki sedikit teman } \\
\text { 14. Memerlukan sedikit bantuan guru }\end{array}$ \\
\hline
\end{tabular}

pendekatan terhadap tugas

f. Standar performa yang tinggi (kadangkala terlalu perfeksionis)

g. Konsep diri yang positif, khususnya dalam kaitan dengan dengan usaha-usaha akademis

h. Perkembangan social dan penyesuaian emosi di atas ratarata (meskipun beberapa anak berbakat yang ekstrim mungkin mengalami kesulitan karena mereka sangat berbeda dari teman-teman sebayanya.

Ohio Association for Gifted

Children (www.oagc.com, 2000) mengemukakan karakteristik dan perilaku yang positif anak berbakat, yaitu sebagai berikut.

\section{Tingkah Laku yang Positif}


Ellen Winner (Ormrod, 2008), seorang ahli bidang kreativitas dan anak berbakat, mendeskripsikan tiga kriteria yang menjadi ciri anak berbakat:

a. Dewasa lebih dini (procecity). Kecenderungan yang muncul pada anak berbakat adalah anak mengalami masa dewasa sebelum waktunya apabila diberi kesempatan untuk menggunakan bakat atau talenta mereka. Konsekuensi logis adanya proses ini adalah mereka mulai menguasai satu bidang tertentu lebih awal dibandingkan dengan teman-teman sebayanya yang tidak berbakat. Hanya saja, mesh mereka lahir dengan bakat alami yang dimiliki dalam bidang tertentu, menjadi kewajiban bagi para orang tua, pendidik untuk dapat lebih menembangkan kemampuan bakat tersebut dengan menyediakan layanan pendidikan yang sesuai dan dibutuhkan mereka.

b. Kecenderungan individu gifted dalam belajar terlihat dengan lebih kuatnya dorongan belajar menuruti kemauan mereka sendii. Lazimnya anak berbakat akan belajar secara berbeda dengan anak lain yang tak berbakat pada umumnya. Dengan begitu pada dasarnya mereka tidak model scafollding dalam belajar (teknik untuk mengubah level bantuan untuk belajar) dan orang dewasa. Kuatnya dorongan belajar atas kemauan sendiri ini pada akhirnya sering menjadikan para anak gifted tidak mau menerima instruksi dari orang lain secara detil. Hanya saja, mesh dalam bidangbidang tertentu yang diidentifikasi keberbakatan mereka-mereka dapat berprestasi dengan membuat penemuan atau memecahkan masalah sendiri dengan cara yang unik, namun boleh jadi kemampuan mereka di bidang normal.

c. Anak-anak gifrted memperlihatkan minat yang besar dan obsesif pada bidang tertentu, Selain hal istimewa sebagai karakteristik anak gifted, dalam kehidupan empiris anak gifted juga mengalami masalah justru terkait dengan karakteristik yang dimilikinya Hasill penelitian yang dilakukan oleh Ohio's State Board of Education (Ohio Gifted Task Force, 2002) mengindikasikan bahwa banyak anak berbakat mengalami "drop out" dari sekolah, karena tidak memperoleh layanan akademik atau pembelajaran yafig dibutuhkan; anak berbakat yang tidak mendapatkan tantangan, atau stimulasi yang dapat mengembangkan potensinya, cenderung kurang siap menerima tantangan, tugas-tugas di sekolah yang lebih tinggi; $85 \%$ anak berbakat mengalami "underachiever", karena mereka tidak memperoleh layanan pendidikan yang diharapkan; mereka sering mengalami rasa bosan, kurang bersemangat, frustrasi, rasa marah, dan merasa kurang berharga.

Mengutip paparan yang diajukan Nurturing The Social Emotional Development of Gifted Children ((Maria, Bagaimana Pendidikan yang Cocok untuk Anak Berbakat dengan Perkembangan Disinkroni?, 11 Desember 2004) tampak jelas betapa pada satu sisi banyak faktor yang dimiliki oleh anak gifted merupakan faktor kuat atau keistimewaannya, namun pada lain sisi hal tersebut justru diprediksi akan menjadi peluang timbulnya masalah yang akan dan hams dihadapi para anak gifted ini. Gambarannya dapat dilihat pada tabel berikut ini: 


\begin{tabular}{|c|c|}
\hline \multicolumn{2}{|c|}{$\begin{array}{c}\text { Masalah Yang Mungkin Dapat } \\
\text { Terjadi Akibat Faktor Kuat } \\
\text { Anak Berbakat }\end{array}$} \\
\hline Faktor Kuat & $\begin{array}{c}\text { Kemungkinan } \\
\text { Masalah }\end{array}$ \\
\hline $\begin{array}{l}\text { Mudah } \\
\text { menerima/mengingat } \\
\text { informasi }\end{array}$ & $\begin{array}{l}\text { Tidak sabaran; tidak } \\
\text { menyukai latihan } \\
\text { dasar }\end{array}$ \\
\hline $\begin{array}{l}\text { Rasa ingin tahu tinggi; } \\
\text { mencari yang } \\
\text { bermakna }\end{array}$ & $\begin{array}{l}\text { Bertanya yang tidak- } \\
\text { tidak/memalukan; } \\
\text { minatnya berlebihan } \\
\end{array}$ \\
\hline Motivasi dan dalam & $\begin{array}{l}\text { Kemauan tinggi; } \\
\text { tidak suka campur } \\
\text { tangan orang lain }\end{array}$ \\
\hline $\begin{array}{lr}\text { Senang menyelesaikan } \\
\text { masalah; } \\
\text { membuat dapat } \\
\text { abstraksi \& } & \text { kintensep, } \\
\end{array}$ & $\begin{array}{l}\text { Tidak suka hal-hal } \\
\text { rutin; } \\
\text { mempertanyakan } \\
\text { cara pengajaran } \\
\end{array}$ \\
\hline $\begin{array}{l}\text { Mencari hubungan } \\
\text { sebab akibat }\end{array}$ & \begin{tabular}{|l|} 
Tidak menyukai hal \\
yang tidak jelas dan \\
tidak logis, misalnya \\
tradisi dan perasaan \\
\end{tabular} \\
\hline $\begin{array}{l}\text { Menekankan } \\
\text { kejujuran, keadilan, } \\
\text { dan kebenaran }\end{array}$ & \begin{tabular}{|l|} 
Kawatir sekali akan \\
masalah \\
kemanusiaan
\end{tabular} \\
\hline \begin{tabular}{l|} 
Senang \\
mengorganisir \\
berbagai hal
\end{tabular} & $\begin{array}{l}\text { Membuat peraturan } \\
\text { remit; tampil bossy }\end{array}$ \\
\hline $\begin{array}{l}\text { Kosakatanya banyak; } \\
\text { informasinya luas \& } \\
\text { mendalam }\end{array}$ & \begin{tabular}{|lr|}
\multicolumn{2}{|l|}{ Memanipulasi } \\
menggunakan \\
bahasa; & bosan \\
dengan & teman \\
sekolah & \& \\
sebayanya & \\
\end{tabular} \\
\hline $\begin{array}{l}\text { Harapan tinggi akan } \\
\text { diri sendiri dan orang } \\
\text { lain }\end{array}$ & \begin{tabular}{|l|} 
Tidak toleransi, \\
perfeksionis, bisa \\
menjadi depresi \\
\end{tabular} \\
\hline $\begin{array}{l}\text { Kreatif/banyak akal; } \\
\text { senang menggunakan } \\
\text { caranya sendiri }\end{array}$ & \begin{tabular}{|l|} 
Dianggap \\
mengganggu \\
diluar "jalur"
\end{tabular} \\
\hline $\begin{array}{l}\text { Konsentrasinya } \\
\text { intensif; mencurahkan } \\
\text { perhatian yang besar } \\
\text { dan sulit dibelokkan } \\
\text { pada hal yang diminati }\end{array}$ & \begin{tabular}{|lr|}
\multicolumn{3}{|l|}{ Lupa kewajiban dan } \\
orang lain saat \\
sedang konsentrasi; \\
tidak raka \\
disela/diganggu; \\
keras kepala \\
\end{tabular} \\
\hline $\begin{array}{l}\text { Sensitif, empati; ingin } \\
\text { diterima oleh orang } \\
\text { lain }\end{array}$ & $\begin{array}{l}\text { Sensitif terhadap } \\
\text { kritik atau penolakan } \\
\text { dari sebayanya } \\
\end{array}$ \\
\hline $\begin{array}{lr}\text { Energy, semangat } \\
\text { tinggi serta sangat alert }\end{array}$ & $\begin{array}{l}\text { Frustrasi karena tidak } \\
\text { ada kegiatan; tampak } \\
\text { seperti hiperaktif }\end{array}$ \\
\hline $\begin{array}{lr}\begin{array}{l}\text { Independen, mem } \\
\text { bekerja }\end{array} \\
\end{array}$ & Menolak masukan \\
\hline
\end{tabular}

\begin{tabular}{|l|l|}
\hline $\begin{array}{l}\text { bertumpu pada diri } \\
\text { sendiri }\end{array}$ & $\begin{array}{l}\text { sebayanya, tidak bisa } \\
\text { kompromi }\end{array}$ \\
\hline $\begin{array}{l}\text { Bermacam-macam } \\
\text { minat \& kemampuan; } \\
\text { berubah-ubah }\end{array}$ & $\begin{array}{l}\text { Tampil } \\
\text { terorganisasi \& } \\
\text { berantakan; frustrasi } \\
\text { karena kekurangan } \\
\text { waktu }\end{array}$ \\
\hline Rasa humor tinggi & $\begin{array}{l}\text { Sebagiannya dapat } \\
\text { salah menangkap } \\
\text { humomya; mencari } \\
\text { perhatian di kelas } \\
\text { dengan "melawak" }\end{array}$ \\
\hline
\end{tabular}

Sumber: Nurturing The Social Emotional Development of Gifted Children ((Maria, Bagaimana Pendidikan yang Cocok untuk Anak Berbakat dengan Perkembangan Disinkroni?, 11 Desember 2004)

Sebagai misal adanya karekteristik mudah menerima atau mengingat informasi justru di satu sisi menumbuhkan rasa ke-tidak sabaran dalam diri individu anak gifted. Bagi anak gifted tidak banyak mengalami kesukaran untuk menyerap ataupun mengolah informasi yang mereka terima, sehingga bagi mereka saat guru menerangkan satu materi tertentu cukup satu kali diterangkan/dijelaskan, dan mereka akan segera mengerti atau memahami informasi.

Bukan hanya itu, informasi yang mereka terima ini selanjutnya diolah mereka yang kemudian dikembangkan seeara leih baik. Sebaliknya, bagi individu normal, menerima, menyerap dan mengolah informasi tentunya bukan hal yang mudah jika dibandingkan dengan mereka yang gifted. Mengingat kesulitan-kesulitan yang dihadapi anak "biasa nomal" ini, tentunya guru akan mengulang penjelasannya. Masalah yang kemudian timbul pada anak gifted adalah mereka akan mengalami kebosanan, jika diharuskan mendengan penjelasan yang sama secara berulang.

Dengan mengutip Jean-Charles Terrasier, Maria Van Teil menyatakan bahwa saat ini sering ditemui adanya 
anak gifted yang mengalami disinkronisasi, yaitu adanya ketidak sinkronan perkembangan anak-anak gifted yang kemudian berakibat dalam berbagai perkembangan perilaku yang menyimpang dari pola umum, sekaligus juga mengakibatkan berbagai prestasi yang tidak seimbang dari anak-anak ini dan berbuntut pada kefrustrasian, agresivitas, penarikan dan isolasi diri, pelepasan energi secara negatif, rendah diri, jatuhnya prestasi di sekolah, dan mudah tersinggung. Pada akhirnya situasi ini menyebabkan potensi keberbakatannya menjadi tertutupi oleh masalah yang dimilikinya

Selain itu, Van der Kolk-Woltha.r (Maria, Gifted atau Autisme: Bagaimana membedakannya?, 11 December 2004) juga menyatakan bahwa pada anak gifted terjadi juga kesulitan dalam proses bermain dengan teman sebayanya. Berbagai kesulitan bermain dengan teman sebaya, bukan hanya karena anak-anak ini mempunyai seleksi permainan yang sangat tinggi, tetapi juga karena gaya berfikir yang berbeda (global dan perfeksionis), gerak motorik yang berbeda, tetapi juga anakanak ini eigenwijs (mengikuti keinginan dirinya sendiri), dalam bermain bersama tidak mau dicampuri.

Bukan hanya itu, ada juga individu gifted yang disebut Twice Exceptional Gifted (anak gifted dengan keistimewaan ganda) atau kadang disebut juga Gifted with Learning Disable (anak gifted dengan gangguan belajar) (Maria, Bagaimana Pendidikan yang Cocok untuk Anak Berbakat dengan Perkembangan Disinkroni?, 11 Desember 2004). Lebih lanjut diungkap Maria bahwa sekalipun dalam berbagai tes inteligensia menunjukkan profil verbal dan performal yang tidak harmonis ternyata bukan berarti kemudian anak ini kelaknya akan mengalami learning disabilities (kesulitan belajar seperti disleksia, diskalkulia, disgrafia).
Hasil penelitian Judith Reuver (Maria, Bagaimana Pendidikan yang Cocok untuk Anak Berbakat dengan Perkembangan Disinkroni?, 11 Desember 2004) menunjukkan bahwa anak-anak yang mempunyai profil tidak harmonis itu belum tentu akan menyebabkan learning disabilities, sedangkan kesulitan membaca, mengeja, berhitung, dan menghapal lebih banyak disebabkan karena gaya berpikir anak gifted yang simultan dan global (gestalt) yang disebabkan karena is adalah seorang anak yang visual learner.

Dipahami bahwa dalam model persekolahan yang biasanya, peserta didik diajarkan untuk berpikir dengan cara runtut, Tinier, konvergen, dan sekuensial. Pada sisi lain, anak-anak gifted memiliki model berpikir simultan, global dan divergen. Adanya perbedaan cara berpikir ini menyebabkan anak gifted tidak mampu menyesuaikan diri dengan anak-anak pada umumnya. Ketidak mampuan menyesuaikan diri ini pada akhirnya akan menjadikan anak-anak gifted mengalami tekanan, kesulitan untuk berkonsentrasi, berperilaku berbeda, yang pada ujung-ujungnya akan mengakibatkan terjadinya gangguan pada prestasi. Bahkan tidak jarang karena kesulitan mereka untuk berkonsentrasi anak gifted ini sering didiagnosis mengalami gangguan konsentrasi, dan karena perilaku mereka juga diagnosis hiperaktif, dalam bahasa psikologi mereka mengalami ADHD (Attention deficit hiperactive disorder).

Dengan kemampuan keberbakatan yang dimilikinya, seorang anak kerap mengalami hal-hal yang tidak diharapkan dalam proses interaksinya dengan teman sebayanya. Dipahami bahwa anak yang diindikasikan memiliki keberbakatan (gifted) biasanya memiliki beberapa kemampuan di atas teman-temanya. Perkembangan dan cara berpikir 
mereka yang terkadang "nyeleneh" menurut anggapan umum yang sebenarnya menjadi salah satu ciri mereka yang berpikir kreatif. Lantas apa yang terjadi pada mereka? Sudah dapat diduga, akan banyak muncul label negatif pada mereka karena perilaku mereka tersebut.

\section{Mengenali Anak Berbakat}

Anak yang memiliki bakat istimewa umumnya bukan hanya dapat belajar dan mengolah informasi secara lebih cepat dibanding dengan teman sebayanya, tetapi juga sering menggunakan cara yang berbeda dan teman-teman seusianya dalam menghadapi masalah yang sama. Tentu saja hal ini terkadang membuat guru di sekolah mengalamai kesulitan, bahkan sering merasa terganggu dengan anakanak seperti itu. Sebab dipahami biasanya para guru lebih menginginkan adanya kebersamaan dalam proses pembelajarannya yang sebenarnya hal ini hanya untuk mempermudah sang guru Baja. Freeman (Freeman, 1985) menambahkan beberapa karakteristik gejala anak yang memiliki keberbakatan:

1) seringkali lahir sebagai bayi besar dan berat

2) sering menunjukkan bunyi-bunyian (menangis, membuat bunyibunyian)

3) banyak gerak dan hidup, mempunyai banyak energi

4) sangat dini sudah menginginkan dan dapat mengangkat kepala

5) menunjukkan perhatian yang besar dan ingin melihat segala sesuatu

6) sangat tidak sabaran dan selalu tegang

7) sangat dini sudah mempunyai kontak mata

8) menginginkan penerapan segera apa yang diketahuinya, atau sibuk menerapkan ke suatu tujuan, semuanya itu atas kebutuhan dorongan motivasi intemalnya, dan tidak bisa digantikan karena adanya pujian, penghargaan, atau hadiah

9) sangat kuat dengan keinginan dan kearah perfeksionisme

10) mempunyai daya ingat yang sangat kuat

11) mempunyai hubungan emosi yang kuat dengan apa yang tengah dikerjakannya, misalnya dalam bidang ilmu-ilmu mumi, bahasa, seni, musik, sosial, bidang psikomotor atau praktis

12) sangat baik dalam hal : bicara, melakukan abstraksi, generalisasi milai dan hal yang sederhan sampai yang istimewa, pemahaman terhadap pengertian-pengertian, dan peletakan hubungan

13) mempunyai rasa ingin tahu intelektualitas yang besar

14) mudah menerima pelajaran

15) mempunyai bidang minatan yang Inas

16) mempunyai perhatian yang besar pada pemecahan masalah dan melakukan realisasi berbagai minatnya

17) penggunaan bahasa baik secara kualitas maupun kuantitas berada di atas teman sebaya

18) mandiri dan sangat efektif dalam bekerj a

19) dapat membaca di usianya yang masih sangat dini

20) mempunyai kemampuan observasi yang baik

21) menunjukkan inisiatif dan orijinalitas dalam kerja intelektual

22) bereaksi secara alert dan cepat mendapatkan ide-ide baru

23) cepat mengingat sesuatu

24) mempunyai perhatian yang besar dalam hal-hal kemanusian

25) mempunyai imajinasi yang luar biasa

26) mudah mengikuti petunjuk yang kompleks

27) pembaca cepat

28) mempunyai banyak hobby

29) senang membaca berbagai macam 
hal

30) menggunakan perpustakaan secara efektif

31) sangat pandai dalam matematika/berhitung, terutama dalam hal pemecahan masalah.

Saat anak gifted di kelas-kelas Taman Kanak-Kanak atau Sekolah Dasar anak-anak berbakat sering tidak menunjukkan prestasi yang menonjol. Sebaliknya justru menunjukkan perilaku yang kurang menyenangkan, misalnya: tulisannya tidak teratur, mudah bosan dengan cara guru mengajar, terlalu cepat menyelesaikan tugas tetapi kurang teliti, dan sebagainya. Mereka cenderung memiliki minat dan perhatian pada halhal yang justru tidak diajarkan di kelas.

Tulisan anak berbakat sering kurang teratur karena ada perbedaan perkembangan antara perkembangan kognitif (pemahaman, pikiran) dan perkembangan motorik, dalam hal ini gerakan tangan dan jari untuk menulis. Perkembangan pikirannya jauh lebih cepat daripada perkembangan motoriknya. Demikian juga seringkali ada perbedaan antara perkembangan kognitif dan perkembangan bahasanya, sehingga dia menjadi berbicara agak gagap karena pikirannya lebih cepat daripada alat-alat bicara di mulutnya.

\section{Pembahasan}

Islam menyadari bahwa kedudukan orang yang berilmu begitu penting dalam struktur masyarakat, sehingga Allah SWT dalam bagian akhir ayat 11 Surat $\mathrm{Al}$ Mujadilah, yang bunyinya:

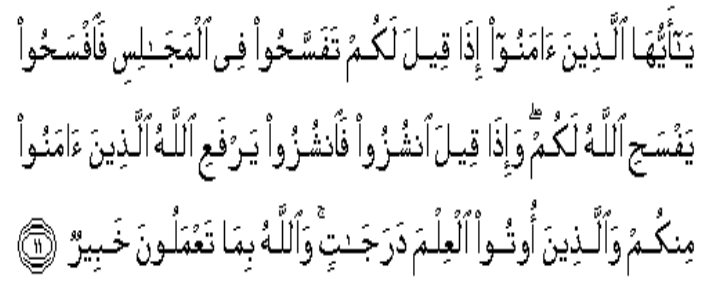

Artinya: Hai orang-orang beriman apabila kamu dikatakan kepadamu:
"Berlapang-lapanglah dalam majlis", Maka lapangkanlah niscaya Allah akan memberi kelapangan untukmu. dan apabila dikatakan: "Berdirilah kamu", Maka berdirilah, niscaya Allah akan meninggikan orang-orang yang beriman di antaramu dan orang-orang yang diberi ilmu pengetahuan beberapa derajat. dan Allah Maha mengetahui apa yang kamu kerjakan.

Pada bagian akhir ayat di atas ditegaskan oleh Allah SWT, bahwa mereka yang beriman dan berilmu akan diangkat derajatnya (diberi kelebihan dari orang-orang yang tidak memiliki ilmu) beberapa derajat. Secara tersirat ayat ini menunjukkan penghargaan lebih Allah SWT pada mereka yang berilmu. Selain itu, wahyu yang pertama diterima oleh Nabi Muhammad SAW adalah ayat yang mendorong untuk belajar, yaitu :
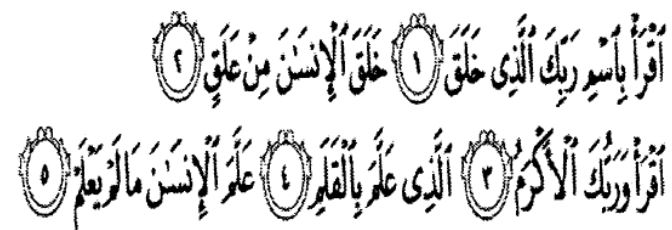

Artinya: (1) Bacalah dengan (menyebut) nama Tuhanmu yang Menciptakan; (2). Dia telah menciptakan manusia dari segumpal darah; (3) Bacalah, dan Tuhanmulah yang Maha pemurah; (4) Yang mengajar (manusia) dengan perantaran kalam; (5) Dia mengajar kepada manusia apa yang tidak diketahuinya.

Wahyu di atas tidak ditujukan pada individu tertentu dengan klasifikasi tertentu, tetapi untuk semua manusia. Dengan begitu, tidak ada pengecualian bagi individu manapun termasuk yang memiliki kebutuhan khusus untuk menempuh jalur pendidikan. Bahkan secara khusus dalam Al-Qur'an dipaparkan peristiwa saat Nabi Muhammad SAW ditegur oleh Allah SWT karena pada awalnya tidak memperhatikan seorang buta yang bernama Abdullah bin Ummi Maktum. Dia datang kepada

Rasulullah s.a.w. meminta ajaran-ajaran tentang Islam; lalu Rasulullah s.a.w. 
bermuka masam dan berpaling daripadanya, karena beliau sedang menghadapi pembesar Quraisy dengan pengharapan agar pembesar-pembesar tersebut mau masuk Islam.

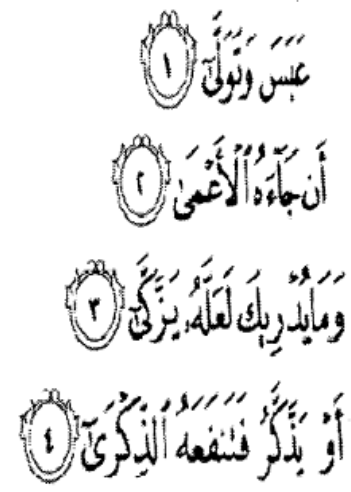

Artinya: (I) Dia (Muhammad) bermuka masam dan berpaling; (2) Karena telah datang seorang buta kepadanya; (3) Tahukah kamu barangkali is ingin membersihkan dirinya (dari dosa); (4) Atau Dia (ingin) mendapatkan pengajaran, lalu pengajaran itu memberi manfaat kepadanya?

Dan ayat-ayat di atas, ada beberapa hal yang dapat disimpulkan terkait - dengan pendidikan bagi mereka yang berkebutuhan khusus:

I. Dalam perspektif Islam pendidikan bukan hanya sekadar hak tetapi juga merupakan kewajiban sebagai prasyarat untuk memahami kewajiban Islam. Dalam konsep pendidikan inklusi pendidikan merupakan hak asasi manusia. Pernyataan pendidikan sebagai hak atau kewajiban bukan sesuatu yang perlu diperdebatkan karena perbedaan hanya terletak pada sudut pandang terhadap substansi yang sama: 'pendidikan sebagai hak' lebih antroposentris dan 'pendidikan sebagai kewajiban' lebih teosentris. Pada sisi ini setiap individu siapapun berhak untuk memperoleh pendidikan, dan sudah seharusnya akses terhadap pendidikan tidak terhalangi hanya karena faktorfaktor ketidak-mampuan fisik (cacat) yang dideria oleh individu. Dan sisi ini, elan pendidikan inklusif sebagai sebuah model pendidikan sangat sejalan dengan konsep-konsep pendidikan dalam ajaran agama Islam. Berkenaan hal itu tampak adanya kesejalanan antara model pendidikan inklusif dengan ajaran dalam agama Islam terkait dengan konsep global bahwa pendidikan merupakan hak bagi semua, education for all.

2. Menyadari bahwa pendidikan merupakan hak bagi setiap individu tanpa memandang ras, agama, budaya, ataupun kecacatan fisik yang dimilikinya, maka pada dasamya proses pendidikan dan hak memperoleh akses pendidikan menjadi hak setiap individu. Artinya, siapapun, di manapun dan dalam kondisi apapun tidak boleh termarjinalkan (nonsegregasi) dalam memperoleh akses pendidikan. Dengan begitu bagi mereka yang mengalami hambatan secara fisik tidak lalu dengan sendirinya juga dipinggirkan dalam memperoleh akses pendidikan. Bagi mereka yang berkebutuhan khusus-juga diberi hak untuk memperoleh akses pendidikan, dan saat mereka masuk dalam komunitas pendidikan harus mendapat perlakuan yang sama dengan yang normal, tanpa membedakan.

3. Simpulan lain yang patut dikedepankan adalah adanya kesamaan pandang antara pendidikan inklusif dengan ajaran Islam dalam memandang individu peserta didik. Islam mengajarkan bahwa setiap individu memiliki posisi yang sama di hadapan Allah SWT sebagaimana tercantum dalam bagian akhir surat al Hujurat ayat 13 yang berbunyi :

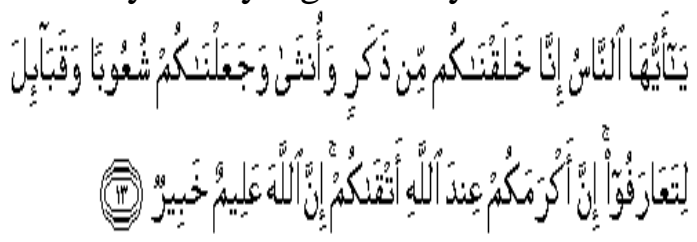

Artinya: Hai manusia, Sesungguhnya Kami menciptakan kamu dari seorang laki-laki dan seorang perempuan dan 
menjadikan kamu berbangsa -bangsa dan bersuku-suku supaya kamu saling kenal-mengenal. Sesungguhnya orang yang paling mulia di antara kamu disisi Allah ialah orang yang paling taqwa diantara kamu. Sesungguhnya Allah Maha mengetahui lagi Maha Mengenal.

Islam mengakui setiap individu memiliki potensi yang khas, yang membedakan dirinya dengan orang lain mungkin karena jenis kelamin, kebangsaan, ras, adat budaya, ataupun agama- tetapi memiliki derajat dan martabat yang sama, dan yang membedakannya adalah sisi ketaqwaannya. Dan sisi ini, baik pendidikan inklusif ataupun ajaran Islam mengajarkan kesamaan dalam memandang setiap individu dengan potensinya yang khas.

Thomas Jefferson (1743-1826) pernah mengajukan konsepnya yang dikenal dengan istilah Diffusion of Education yang menekankan bahwa setiap orang seharusnya mendapatkan kesempatan untuk mengembangkan bakat-bakat yang tidak sama, sehingga mereka pun akan menerima pelayanan pendidikan yang sesuai dengan kebutuhannya. Demikian pula halnya dengan anak-anak gifted ini, sudah seharusnya dan sepantasnya mereka mendapatkan layanan pendidikan yang sesuai untuk menumbuh-kembangkan potensi keberbakatan yang mereka. Hal ini sejalan dengan pendapat Purwanta (2012), bahwa untuk mencapai tujuantujuan tersebut, anak hendaknya difasilitasi untuk mendapatkan kesempatan 1) mengenal dan memahami potensi, kekuatan, dan tugas-tugas perkembangannya; 2) mengenal dan memahami potensi atau peluang yang ada di lingkungannya; 3) mengenal dan menentukan tujuan dan rencana hidupnya serta rencana pencapaian tujuan tersebut; 4) memahami dan mengatasi kesulitan-kesulitan sendiri; 5) menggunakan kemampuannya untuk kepentingan dirinya, kepentingan lembaga tempat bekerja dan masyarakat; 6) menyesuaikan diri dengan keadaan dan tuntutan dari lingkungannya; dan; 7) mengembangkan segala potensi dan kekuatan yang dimilikinya secara optimal. Adanya fasilitas memadai dapat digunakan untuk membantu anak dalam mengembangkan kemampuan secara optimal.

Winner (Ormrod, 2008), menyatakan bahwa sering kali anak-anak berbakat akan terisolasi secara sosial dan tidak mendapat tantangan yang berarti di kelas. Terlebih jika model pengajaran yang diberikan guru tidak memiliki daya tank. Tentunya situasi ini menjadikan mereka cepat merasa bosan, tidak termotivasi, cenderung mengganggu teman-teman lainnya. Pada ujungujungnya karena perilaku mereka inilah banyak kalangan pendidikan menggolongkan mereka sebagai anak "nakal".

Sebenarnya kondisi anak gifted yang tidak tertantanglah yang menjadikan mereka berperilaku "nakal", bolos sekolah, mengganggu teman atau bersikap pasif. Untuk itu sudah seharusnyalah kepada mereka diberikan layanan pendidikan yang dapat menarik minat mereka, menantang dan meningkatkan daya kreativitas mereka. Model pendidikan tradisional dengan memasukkan mereka pada sekolah reguler memiliki titik lemah. Pertama, anak berbakat mungkin akan mengalami frustasi, karena mereka tidak mendapatkan layanan pendidikan yang mereka harapkan. Kedua, karena rasa frustasi mereka ini, maka perilaku yang justru muncul adalah perilaku mengganggu teman-temannya, dan jika ini terjadi dengan sendirikan' kelas juga akan terganggu. Ketiga, muncul rasa bosan yang pada akhirnya menjadikan mereka enggan untuk masuk kelas.

Untuk itu, bagi mereka yang diidentifikasi memiliki keberbakatan, maka layanan pendidikan yang dapat dilakukan antara lain: 
a. Mengelompokkan pada kelas khusus, yaitu siswa yang diidentifikasi memiliki keberbakatan dimasukkan dalam kelas khusus, dengan para peserta didik yang memiliki tingkat kemampuan yang sama. Adanya kemampuan yang sama ini akan menjadikan setiap individu dalam kelas tersebut merasa tertantang, dan pada akhirnya mereka akan menunjukkan kemampuan mereka yang sebenarnya. Metode kelas khusus ini tentunya tidak memungkinkan dengan jumlah peserta didik yang banyak, tetapi terbatas pada anak-anak pilihan yang oleh Plato disebut sebagai "men of gold". Tentunya desain kelas khusus bukan hanya sekadar mengelompokkan anak gifted dalam kelompok yang sama saja, tetapi juga hams mendesain ulang model pembelajarannya, kurikulum yang digunakan, sistem evaluasi yang diterapkan, model pemberian tugas.

b. Program Akselerasi. Program akselerasi adalah memindahkan murid secepat mungkin sesuai dengan kemajuan belajar dan kemampuan yang dimiliki individu belajar. Pemindahan dalam proses ini memasukkan individu belajar pada kelas sesuai dengan kemampuan yang dimiliki oleh yang bersangkutan. Tentunya proses pemindahan ini dapat dilakukan jika telah terlebih dahulu dilakukan tes akademik pada peserta didik tersebut, sehingga yang bersangkutan dapat ditempatkan sesuai dengan kemampuan yang dimiliki.

Terkait dengan strategi khusus untuk meningkatan perkembangan keberbakatan yang dimiliki nak-anak gifted ini, Ormrod (2008) mengajukan beberapa alternatif cara yaitu :

a. Berikan tugas-tugas yang terindividualisasi, yaitu tugas yang disesuaikan dengan kemampuan individual peserta didik; b. Bentuklah kelompok belajar yang terdiri dan siswa-siswa yang memiliki minat dan kemampuan yang serupa;

c. Ajarkan keterampilan kognitif yang kompleks dalam konteks mata pelajaran tertentu;

d. Berikanlah kesempatan untuk melakukan kajian secara mandiri tentang satu topik tertentu;

e. Dorong siswa untuk menerapkan sasaran yang tinggi

f. Mencari sumber daya dari luar.

Supriyadi (1992) dalam tulisannya mengemukakan bahwa program pendidikan anak-anak berbakat mungkin berupa :

a. program pengayaan dalam kelas biasa;

b. tersedianya guru tertentu yang bertugas sebagai konsultan bagi anakanak berbakat;

c. tersedianya ruangan yang berisi sumber-sumber belajar yang dapat mereka manfaatkan untuk pengayaan;

d. tersedianya mentor khusus untuk melatih mereka dalam keterampilanketerampilan tertentu, dan mentor ini bukan staf pengajar, melainkan ahli yang disewa oleh sekolah untuk kepentingan anak;

e. studi mendiri dalam bentuk proyek, misalnya proyek penelitian tentang jenis bebatuan, flora, fauna, dll;

f. kelas-kelas khusus berdasarkan minat siswa, misalnya kelas untuk mata pelajaran matematika, fisika, biologi, geografi, sejarah, drama, dan taxi.

Selain itu kiat lain dapat berupa:

a) Memberi kesadaran kepada mereka untuk tidak menjadi Mr/Mrs. Perfeksionis. Hal ini penting untuk dilakukan agar mereka juga menyadari keterbatasan kemampuan yang mereka miliki, sehingga seandainya mereka membuat satu kesalahan dalam pengerjaan tugas-tugasnya, maka hal itu hendaklah ditanggapi sebagai suatu kewajaran, dan jangan dijadikan sebagai penghambat untuk melakukan kreativitas berikutnya.

b) Merujuk pada model triadik yang 
diajukan Monk dan Renzulli, maka pemberdayaan aktif aspek keluarga, sekolah dan lingkungan masyarakat menjadi sangat penting. Hal ini dibutuhkan agar siswa memiliki peluang seluas-luasnya untuk mengembangkan keberbakatan yang dimiliki. Dengan begitu jangan sampai terjadi satu aspek tertentu tidak mendukung aspek lain, atau bahkan masing-masing aspek saling menjatuhkan. Tentunya situasi tidak dapat mendukung optimalisasi keberkembangan aspek keberbakatan yang dimiliki siswa.

c) Orangtua sebagai pendidik pertama dan utama, hendaklah dapat menemu kenali potensi keberbakatan yang dimiliki anak, sehingga potensi ini dapat dikembangkan sejak awal masa kanakkanak. Banyak hasil penelitian merekomendasikan tentang pentingnya pola pengasuhan untuk keberhasilan individu. Selain itu peran orang terdekat (signifikan people), teman sebaya, lingkungan sekitar (budaya setempat) penting bagi pengembangan keberbakatan anak gifted ini.

d) Mengingat keberbedaan yang dimiliki anak berbakat ini, maka desain pembelajaran yang seharusnya mereka terima adalah:

e) Kurikulum yang terdiferensiasi, yang memiliki tingkat fleksibilitas tinggi, sehingga memungkinkan anak gifted ini melakukan proses pembelajaran dengan tidak terikat pada jenjang dan kelas tertentu untuk masa yang lama;

f) Penciptaan lingkungan belajar yang kondusif.

Dalam tulisannya Idrus (2001) menyatakan bahwa lingkungan belajar bukan hanya sekadar lingkungan fisik yang terdiri dan penataan ruang, kursi, meja, papan dan alat bantu lain yang berada di kelas, ataupun yang berada di luar kelas, namun juga lingkungan emosional berupa interaksi antara pendidik-siswa, siswa-siswa. Sebagai pendidikan komponen lingkungan tersebut hams dapat dikembangkan agar siswa dapat belajar dengan senang di kelas.

Terkait dengan penciptaan lingkungan belajar kondusif ini, Gallagher (Gallagher, 1985) mengemukakan beberapa hal yang terkait dengan upaya menciptakan lingkungan belajar yang kondusif bagi anak berbakat, yaitu sebagai berikut.

a. Memberikan program pengayaan, dalam hal ini guru memberikan

materi atau pelajaran khusus dalam rangka membantu perkembangan anak.

b. Menugaskan "guru konsultan", yaitu guru yang memiliki keterampilan khusus untuk memberikan materi atau pelajaran yang tepat kepada anak.

c. Menyediakan ruang sumber (laboratorium), di mana anak dapat mengembangkan keterampilan atau kemampuan tertentu.

d. Menggunakan mentor (resource person), warga masyarakat yang memiliki keterampilan atau kompetensi dalam hal tertentu yang sangat dibutuhkan untuk membantu perkembangan anak, seperti ilmuwan, dan seniman

e. Memberikan latihan kepada anak untuk melakukan studi mandiri (independent study), seperti melakukan penelitian tentang transportasi.

f. Menyediakan kelas-kelas khusus berdasarkan minat siswa, seperti kelas fisika, biologi, matematika, kimia, sejarah, dan seni.

Penciptaan lingkungan belajar yang kondusif bagi anak berbakat dapat juga berupa:

a. Menciptakan iklim kelas yang mengundang atau mendorong anak untuk belajar secara inquiry (terdapat gambar-gambar, buku-buku, alat-alat musik, dsb.).

b. Menggunakan pengajaran tematik yang bersifat kontekstual.

c. Mengembangkan cakupan materi pelajaran secara luas.

d. Menyediakan puast-pusat kegiatan untuk mengerjakan tugas-tugas atau pengembangan diri. 
e. Menyiapkan tempat duduk (kursi meja) yang dapat dirubah posisinya secara fleksibel.

f. Menyiapkan materi pelajaran atau kegiatan khusus bagi siswa yang dapat mengerjakan atau menyelesaikan pelajarannya lebih cepat dari yang lain.

g. Menciptakan suasana ruangan kelas yang menyenangkan, seperti penggunaan musik untuk menyertai anak belajar.

h. Menghadirkan guru yang memang profesional dalam membina anak-anak berbakat. Selama ini dalam sekolahsekolah umum jarang atau bahkan tidak memiliki guru yang memiliki kemampuan untuk membimbing anak dengan kemampuan keberbakatan. Guru atau pembimbing yang qualified akan memungkinkan potensi keberbakatan berkembang secara optimal.

\section{Kesimpulan}

Keberbedaan anak berbakat ini hendaknya dijadikan sebagai sebuah rahmat dengan cara memberikan layanan pendidikan yang sesuai dengan kemampuan dan tingkat perkembangan yang dimiliki anak-anak gifted tersebut. Kesalahan diagnosis dan pelayanan yang diterima anak akan menjadikan mereka frustasi, rendah diri dan hilang potensi keberbakatannya.

Orang tua sebagai pendidik utama dan pertama hendaklah secara dini menemu-kenali karakteristik anak- anak mereka yang memiliki kecenderungan berbakat, sehingga dapat memberikan layanan pendidikan yang sesuai dengan kebutuhan mereka.

Adapun guru dan sekolah, tentunya memiliki peran yang tidak sedikit untuk lebih berkembangnya anak-anak ini dengan memberikan model pembelajaran yang lebih mengakomodasi potensi yang dimiliki. Mengubah paradigma anak berbakat sebagai para trouble maker si pembuat onar, dan menghilangkan segala label pada anak-anak ini menjadi sangat penting, agar mereka tidak rendah diri dalam pergaulannya.

Teman sebaya dan lingkungan juga memiliki peran yang signifikan dalam proses pengembangan anak-anak dengan kemampuan istimewa ini. Perlakuan yang sama adalah yang sangat diharapkan oleh mereka yang diindikasi memiliki keberbakatan, penerimaan dengan setulusnya menjadi kunci keberhasilan pergaulan mereka. Pada nisi tersebut peran teman sebaya menjadi sangat penting, agar anak-anak berbakat ini tidak terisolir.

\section{Referensi}

Akbar, R., \& Hawadi. (12 Januari 2002). Konsepsi Program percepatan Belajar bagi Anak Berbakat Intelektual. Seminar Program Akselerasi Jenjang SLTP. SMU. Jakarta: Gedung UKRIDA, Jakarta.

Bainbridge, C. (2014). Retrieved August 31, 2014, from Educational Options and Issues of Gifted Children: http://giftedkids.about.com/od/educat ionoptions/u/education.htm

Children, 0. A. (2000). Retrieved April 17, 2014, from What to Expect When: You're Raising A Gifted Child: www.oagc.com

Ford, D. Y., Ford, D. Y., \& Trotman, M. F. (2001). Teachers of Gifted Students:

Suggested Multicultural Characteristics and Competencies. Roeper Review:. A Journal on Gifted Education. www.roeperreview.org, Pp. 235-239.

Freeman, J. (1985). The psychology of gifted children Perspective on Development and Education. Great Britain: St. Edmunsburry Press.

Gallagher, J. J. (1985). Teaching The Gifted Child. Massachussetts: Allyn and Bacon,Inc.

Idrus, M. (2001). Desain belajar yang menyenangkan. Jurnal studi Isalam

Mukaddiman No. 11 Th. VII/200. Kopertais III dan PTAIS Yogyakarta.

Johnsen, S. (2005).Within-class Acceleration. Gifted Child Today. Winter, 2005; 28, 1, p. 5. 
Maria, J. V. (11 December 2004). Gifted atau Autisme: Bagaimana membedakannya? Seminar GiftedAutisme-ADHD Penanganan dan Permasalahannya. Yogyakarta: Fakultas Kedokteran Universitas Gadjah Mada Yogyakarta.

Maria, J. V. (11 Desember 2004). Bagaimana Pendidikan yang Cocok untuk Anak Berbakat dengan Perkembangan Disinkroni? Seminar Gified-Autisme-ADHD Penanganan dan Permasalahannya. Yogyakarta: Fakultas Kedokteran Universitas Gadjah Mada Yogyakarta.

Marland, S. J. (1985). Education of the Gifted and Talented. Volume 1. Report to the Congress of the United States by the US Commissioner of Education, US Government Printing Office,. In J. Freeman, The psychology of gifted children. Perspec. Great Britain: St. Edminsburry.

Monks, J. F., \& Boxtel, H. W. (1985). Gifted Adolescents: A developmental Perspective. In J. Freeman, The psychology of gifted children. Perspective on Development and Education. Great Britain: St. Edmunsburry Press.

Ohio Gifted Task Force. (2002). Gifted in the 21'st Century (A Report of
Findings and Recommendations). Ohio.

Ormrod, J. E. (2008). Educational Psychology Developing Lerners. New York: Merrill Prentice Hall.

Purwanta, Edy. (2012). Upaya Meningkatkan Eksplorasi Karier Anak Berkebutuhan Khusus. PPSIKOPEDAGOGIA Jurnal Bimbingan dan Konseling, 1 (2): 1-9.

Semiawan, C. R., Munandar, A., \& Munandar, S. C. (1984). Memupuk bakat dan kreativitas siswa sekolah menengah: petunjuk bagi guru dan orang tua. Jakarta: PT. Gramedia.

Smutny, J. F. (2000, Mei). Gifted Education Digest. Retrieved August 31, 2014, from Teaching Young Gifted Children in the Regular Classroom ERIC EC Digest \#E595 Pengarang: Mei 2000 ERIC Clearinghouse on Disabilities and Gifted Education http://ericec.org

Supriadi, D. (1992). Perspektif Psikologis dan Sosial Pendidikan Anak-anak Berbakat. Konvensi Nasional Pendidikan Indonesia II. Medan.

http://www.gifted.uconn.ed/siegle/TAG/Di ge sts/e595.html

www.oagc.com . (2000). What to Expect When...You're Raising A Gifted Child. Ohio: Ohio Association for Gifted Children. 